\title{
Optimal Portfolio Allocation among REITs, Stocks, and Long-Term Bonds: An Empirical Analysis of US Financial Markets
}

\author{
Rafiqul Bhuyan $^{1}$, James Kuhle ${ }^{2}$, Nuriddin Ikromov ${ }^{2}$, Charles Chiemeke ${ }^{1}$ \\ ${ }^{1}$ American University of Kuwait, Kuwait City, Kuwait \\ ${ }^{2}$ California State University, Sacramento, USA \\ Email: rbhuyan@auk.edu.kw, kuhlejl@csus.edu, ikromovn@csus.edu, cchiemeke@auk.edu.kw
}

Received December 17, 2013; revised January 21, 2014; accepted January 30, 2014

Copyright (C) 2014 Rafiqul Bhuyan et al. This is an open access article distributed under the Creative Commons Attribution License, which permits unrestricted use, distribution, and reproduction in any medium, provided the original work is properly cited. In accordance of the Creative Commons Attribution License all Copyrights (c) 2014 are reserved for SCIRP and the owner of the intellectual property Rafiqul Bhuyan et al. All Copyright (C) 2014 are guarded by law and by SCIRP as a guardian.

\section{ABSTRACT}

Using mean-variance utility function analysis with various degrees of risk aversion, this research examines the impact of Real Estate Investment Trusts (REITs) in creating optimal portfolios. It also examines and develops a sensitivity analysis for differential risk premiums in REIT stocks and the effect in determining an optimal portfolio mix by applying mean variance analysis. When the combined risk premium of REITs and stocks is $1.5 \%$, we find investors with risk aversion between 1 and 6 are better off investing almost entirely in REITs, short selling the bond and investing very little in stocks. Investors can benefit in the same way even when the risk premium of REITs and stock is fixed at $2.0 \%$ with risk aversion equal to between 1 and 9 . However, when the risk premium of REITs and stock is fixed at $2.5 \%$, the investor's risk aversion factor is irrelevant, and it suggests investors should short sell the bond and invest mostly in REITs. The marginal effect of changes in (portfolio returns) $r R$ on the optimal portfolio weights in REITs is observed to have a sharp decline when risk aversion is increased. However, the impact of that change in the REIT-Stock correlation is non-existent as the optimal weight in REITs is increased. In addition, there is little obvious change when the risk aversion is increased. Therefore, the change of weights in REITs in the optimal portfolio is more significant than the correlation between REITs and stock performance. Results also indicate that the investor should consider how to maximize their return using various levels of risk aversion and not by using the correlation between stock and REITs.

\section{KEYWORDS}

Mean-Variance Utility; Optimal Portfolio; Risk Aversion; Correlation; REITs

\section{Introduction}

The mean-variance approach in optimal portfolio allocation is a widely used method that investors and institutional fund managers apply in constructing portfolios with multiple, diverse assets. The purpose of applying this method is to create an efficient diversified portfolio that can improve return while minimizing risk levels. This optimization technique can be applied within an asset class by increasing the number of securities from that asset class. It also can be attained by incorporating multiple asset classes and including different securities from different asset classes. Traditionally, stocks and bonds are utilized in forming optimal portfolios. Investors, including institutional players, have examined various types of assets to combine together to achieve the optimal portfolio. REITs have been an alternative type of investment considered for portfolio inclusion since $1980 \mathrm{~s}^{1}$.

\footnotetext{
${ }^{1}$ A Real Estate Investment Trust (REIT) is best described as a corporation or trust that uses the pooled capital of many investors to purchase and manage income from property. Property income can be derived from many sources. The main source of property income for REITS is rental income [1].
} 
REITs have been one of the most attractive financial investment tools historically that tend to improve the risk/return tradeoff in portfolio creation. REITs have two powerful benefits that are attractive to investors, portfolio balancing/diversification benefits, and an ongoing source of dividend income. The income from REITs has been a stable source of income for investors due to the REITs' ability to adjust quickly to the cost of living and thereby potentially reduce the impact of inflation-related devaluation helping to reduce the impact of inflationrelated devaluation. In addition, the revenue from REITs tends to be predictable because its income comes from the underlying real commercial properties with long-term lease periods. The other important characteristic of REITs is that the investors do not have to pay taxes on that part of the dividend received in the year it is distributed and that amount is also non-taxable until the stock is sold. Empirical findings suggest that REITs have outperformed every major stock market index with 50 percent less risk since 1960 until 2005. Furthermore, the correlation between REITs and stocks are relatively low, making them highly attractive for portfolio choice and diversification. There are also significant benefits to investors in terms of increasing the liquidity of their investment and reducing the systematic risk of their portfolios.

This research examines the impact of the inclusion of REITs in individual investor's optimal portfolio with different degrees of risk aversion. It also examines and develops sensitivity to different risk premiums in REITs and their correlation in the portfolio mix by applying mean variance analysis. This research uses 11 years of historical return data to test the mathematical approach with the assumption that the historical data would not repeat itself. This research employs a mean-variance utility function at different levels of investors risk aversion to examine the security choices under different degrees of risk aversion ranging from one to ten where one is the most aggressive risk level and ten is the most conservative.

This research is presented as follows. Section 2 provides a survey of the related literature. Section 3 describes the source of data and Section 4 describes the empirical methodology used in the research. Section 5 presents the empirical results from the mean-variance estimates. Lastly, Section 6 concludes the research.

\section{Literature Review}

A comprehensive survey of literature regarding diversification benefits of mixed portfolio of stock, bonds, and real estate is summarized in [2,3]. Based on US financial market research, the literature establishes the benefit of diversification using real estate assets based on correlation analysis without considering the dynamics of correlations over time. Nonetheless, real estate and REITs have established their role in the formation of efficient portfolios. Research has quantified that optimal allocations to real estate should be approximately $10 \%$ to $20 \%$ of the total asset allocation [4-8]. Using mean-variance analysis, the optimal portfolio allocation to real estate should be between $5 \%$ and $10 \%$ of total assets [8]. Reference [9], on the other hand, advocates for larger allocations in real estate, suggesting that a full two-thirds of the investor's portfolio should be allocated to real estate. It has been argued that REITs mimic the performance of small cap stocks and hence help form efficient portfolios with much less risk [10]. Examining the impact of incorporating both private real estate and REITs in a mixed asset portfolio finds that the asset categories have very low quarterly correlations and that both asset classes merit inclusion in the portfolio [11]. Reference [11] also finds that unconstrained theoretical allocations to real estate in excess of an astonishing 50\% are optimal. A 20\% allocation to REITs increases expected portfolio returns at most risk levels by 50 basis points, while at the same time reducing portfolio risk to make the portfolio more efficiently allocated [12]. REITs are a better choice in the portfolio choice of individual investors even when the family home is considered as an asset [13,14]. An investigation of a sample of 159 pension funds concludes that actual holdings of real estate are far below what would be considered optimal portfolio levels [15]. A survey of literature indicates that although real estate is optimal in portfolio diversification, the actual amount of real estate held in mixed-asset portfolios is significantly smaller $[16,17]$. The entire REIT market capitalization is equal to only about 3\% of institutional holdings in financial assets. Real estate indeed offers positive impact in mixedasset portfolios $[16,18]$. However, none of the research could identify and agree on an optimal level of real estate in a portfolio. Other surveys in the literature, including [19-22] clearly emphasize that real estate is more than a mere diversifier. They further note in their paper that the REIT is a debt-equity hybrid and as such can provide additional benefits such as a reduction in overall portfolio risk, higher portfolio absolute returns, hedging unexpected inflation or deflation, generation of a wider investment universe, and the delivery of strong cash flows to the investor. More recent studies $[23,24]$ also show that there is significant benefit in diversification using real estate.

There is also potential for international diversification using real estate [25]. Using a cross-sectional data of different countries, [26] finds strong support in international diversification, a finding later confirmed by [27,28]. 
Conditional correlation is low when international real estate is considered compared to domestic real estate [29]. Reference [28] demonstrates a dramatic improvement resulting from diversification in international real estate. References [30-33] show similar benefits using data for the Asia pacific regions.

Contrary results are also observed in the literature. There are variable correlations and returns of stocks, bonds, REITs over sub-periods from 1972 to 1995 [34]. References [35-39] all observe poor return prospects for stocks in the future. The correlation matrix tends to be unstable over time [40-42]. The diversification potential for REITs tend to be time sensitive [43]. Reference [44] observes the benefits of diversification using REITs; however, they also observe that the benefit is time varying due to unstable correlations between real estate assets and stocks. Similar conclusions are drawn in $[25,45]$.

Tactical asset allocation studies by [46-48] have attempted to improve on the historical data in mean-variance analysis. Similarly, [49] uses a QTARCH approach and find portfolio performance improvements from using conditional variances and covariance. On the other hand, [50] estimates predicted means, variances, and covariance, which are then used to construct ex-ante conditional mean-variance efficient portfolios and to study the ex-post return characteristics of these portfolios. Reference [50] finds that based on the conditioning of lagged REIT returns allows for better predictions of volatilities and correlations of REITs with other asset classes. There is some evidence of performance persistence in REITs, which could continue into the second and third year [51]. Expected returns of REITs are significantly different between the pre and the post-1990 sub-periods, and in the post-1990 period, momentum is the dominant predictor of REIT returns [52]. REITs also assume the important role of hedging in optimal portfolio allocation. Those hedging REITs have relatively low correlation to stocks and bonds [22]. For this reason, it REITs can be used to hedge against some investment risks in the stock market. Moreover, REITs could also help investors avoid inflation risk by using the returns on REIT investments to compensate the loss from inflation. Equity REITs are the most effective tools for hedging. Equity REITs (EREITs) are considered as effective hedging tools in portfolios as shown by [14] who report that adding more weights in EREITs improve the efficiency in the optimal portfolios to individual investors. On the other hand, individual investors might earn more profit by investing in REITs. Inclusion of REITs in domestic and international portfolios could contribute to superior performance in a mean-variance framework [53]. Taking the perspective of Canadian and US investors, an all-inclusive optimization technique of including REITs in an international stock portfolio diversified into established and emerging markets, can improve the performance of a real estate portfolio [53]. In [54], investigating Vanguard Real Estate Investment Trust and i-Shares Dow Jones US Real Estate Index Fund exchange traded funds, it was found that the Vanguard Real Estate Investment Trust exchange traded fund is consistently co-integrated with its underlying index the MSCI US REITs Index, before, during and after the financial crisis. But the methodology used in the study is based on a disintegration hypothesis and not on mean-variance framework.

\section{Data}

This research mainly examines the marginal effects of changes in REIT-stock risk premiums and REIT-stock correlation values. The historical total returns data for equity REITs, S\&P 500, and 10-year Treasury Notes for a period of 1997 to 2007 is the considered data set. The monthly total return data for equity REITs is obtained from the National Association of Real Estate Investment Trust (NAREIT). The reason for choosing equity REITs for this study is because the performance of equity REITs is more stable (which) and it has not been significantly affected by the sub-prime loan crisis. Stock and bond historical monthly return data is taken from the global financial data base. The sample period of 11 years from 1997 to 2007 is the observed time period. The sample size is divided separately into three time periods to adequately analyze and observe if there are any differences in the performance of the various time periods when compared to the total overall period. The sample size is separated into three time periods to analyze and determine whether a particular period has any significant difference in performance compared to the total period. The key summary statistics for the data sub-periods are shown in Exhibit 1.

Panel A in Exhibit 1 shows that during the entire sample period, REITs offer an average monthly return of $0.988 \%$ compared to $0.0057 \%$ in stock and $-0.002 \%$ in bonds. Panel B shows the performance for the period of 1997-2002. This is the same period when the stock market had a boom during the 1990s and a bust in 2002. Results still show that REITs offered higher returns during that time compared to stocks and bonds. Panel C shows the performance for the period of 2003-2007. It is the time when the real estate market had one of its best times in the history of USA. Not surprisingly, REITs significantly outperform bonds and stocks. Exhibit 1 also shows the standard deviation and correlations among these three assets. The standard deviation of REITs is observed to 
Exhibit 1. Summary statistics for the data sub-periods.

Panel A: 1997-2007

\begin{tabular}{|c|c|c|c|}
\hline & REITs & Stocks & Bonds \\
\hline Avg. return & $0.9883 \%$ & $0.0057 \%$ & $-0.0020 \%$ \\
\hline Std. dev. & $4.2022 \%$ & $0.0427 \%$ & $0.0582 \%$ \\
\hline REITs & 1 & & \\
\hline Stocks & 0.33 & 1 & \\
\hline Bonds & 0.02 & 0.25 & 1 \\
\hline \multicolumn{4}{|l|}{ Panel B: 1997-2002 } \\
\hline & REITs & Stocks & Bonds \\
\hline Avg. return & $0.5498 \%$ & $0.0030 \%$ & $-0.0061 \%$ \\
\hline Std. dev. & $3.6771 \%$ & $0.0532 \%$ & $0.0526 \%$ \\
\hline REITs & 1 & & \\
\hline Stocks & 0.27 & 1 & \\
\hline Bonds & 0.16 & 0.32 & 1 \\
\hline \multicolumn{4}{|l|}{ Panel C: 2003-2007 } \\
\hline & REITs & Stocks & Bonds \\
\hline Avg. return & $1.5145 \%$ & $0.0089 \%$ & $0.0023 \%$ \\
\hline Std. dev. & $4.7027 \%$ & $0.0246 \%$ & $0.0639 \%$ \\
\hline REITs & 1 & & \\
\hline Stocks & 0.55 & 1 & \\
\hline Bonds & -0.10 & 0.17 & 1 \\
\hline
\end{tabular}

Note: the means, standard deviation, and correlation matrix are based on monthly returns.

be higher relative to stocks and bonds. In addition, the correlation coefficient between REITs and stocks is higher than REITs and bonds. Notice also that the correlation coefficient on the returns of REITs and stocks has increased over time from 0.27 to 0.55 . In this research panel C is considered to be the base-level data for determining the marginal effects between REITs and stocks. Since REIT investment growth is significant during these years, panel $\mathrm{C}$ would be an accurate reflection of more recent years' investment activity in REITs.

\section{Methodology}

This research replicates the model in [44] and considers different time periods and samples of securities. It is assumed that the stock-bond relationship can have an important impact on the findings. This research mainly employs the widely accepted concept of mean-variance portfolio diversification analysis with the basic assumption that risk is measured by variance, and that the decision criterion should be to minimize variance given expected return, or to maximize expected return for a given variance. For investors, the mean-variance could help in constructing an optimal portfolio by minimizing risk as measured by the variance or standard deviation of a security's returns. Assume that investors can choose the portfolio weights for maximizing utility $U$ with the following common function:

$$
U=r_{p-}\left(\frac{1}{2}\right) A * \sigma_{p}^{2}
$$

where "A" represents the investors' risk aversion. Low values of A represent higher tolerance of risk and high values of A represent lower tolerance of risk. A is assumed to range from 1 to 10 levels. The other assumptions implied in this analysis are that financial markets are efficient, the investors can short sell their bond through the market, and the calculation of portfolio which consists of REITs, stock, and bond are shown as follows: 


$$
r_{p}=W_{R} r_{R+} W_{S} r_{S}+W_{B} r_{B} .
$$

In this equation, the $W_{R}, W_{S}$, and $W_{B}$ are the weights of the portfolio which represents the REITs, stocks and bonds respectively. Moreover, $W_{R}, W_{S}$ and $W_{B}$ are all required to be larger than zero and the sum of these three weights is equal to one. In addition, $r_{R}, r_{S}$, and $r_{B}$ also represent the expected return of REITs, stocks and bonds respectively. The structure of the portfolio depends on the investors' risk aversion which can range from one, to two, three or more (10) for the different asset classes. The optimal portfolio weight in REITs $W_{R}^{*}$ which can be found by setting $\partial U / \partial W_{R}$ equal to zero and solving for $W_{R}$. To find the weights of the stocks and bonds in the portfolio, the calculation of $W_{R}^{*}$ would be represented as follows:

$$
W_{R}^{*}=\frac{\left[r_{R}-r_{S}+A\left(\sigma_{S}^{2}-\sigma_{R S}\right)\right]-\left[W_{B}^{*} * A\left(\sigma_{S}^{2}-\sigma_{R S}-\sigma_{R B}-\sigma_{S B}\right)\right]}{A\left(\sigma_{R}^{2}+\sigma_{S}^{2}-2 \sigma_{R S}\right)} .
$$

Here, we can also set $\partial U / \partial W_{B}$ equal to zero to get the calculation for $W_{B}^{*}$ as follows:

$$
W_{B}^{*}=\frac{\left[r_{B}-r_{S}+A\left(\sigma_{S}^{2}-\sigma_{S B}\right)\right]-\left[W_{R}^{*} * A\left(\sigma_{S}^{2}-\sigma_{R S}-\sigma_{R B}-\sigma_{S B}\right)\right]}{A\left(\sigma_{B}^{2}+\sigma_{S}^{2}-2 \sigma_{S B}\right)} .
$$

Since both of the $W_{R}$ and the $W_{B}$ are unknown, the formula can be re-arranged below:

$$
W_{R}^{*}=\frac{\left[r_{R}-r_{S}+A\left(\sigma_{S}^{2}-\sigma_{R S}\right)\right] Y-\left[r_{B}-r_{S}+A\left(\sigma_{S}^{2}-\sigma_{S B}\right)\right] Z}{A\left(X Y-Z^{2}\right)}
$$

where $X=\left(\sigma_{R}^{2}+\sigma_{S}^{2}-2 \sigma_{R S}\right), \quad Y=\left(\sigma_{S}^{2}+\sigma_{B}^{2}-2 \sigma_{S B}\right), Z=\left(\sigma_{S}^{2}-\sigma_{R S}+\sigma_{R B}-\sigma_{S B}\right)$, and $\sigma_{i j}=\rho_{i j} \sigma_{i} \sigma_{j}$.

Therefore, from the above formulas, the weights in the REITs in the optimal portfolio can be obtained. Next, the marginal effect of changes in $r_{R}$ on the optimal portfolio weights in REITs can be found using the following formula:

$$
\partial W_{R}^{*} / \partial r_{R}=\frac{1}{A\left(\sigma_{R}^{2}+\sigma_{S}^{2}-2 \rho_{R S} \sigma_{R} \sigma_{S}\right)}>0 .
$$

This equation is designed to represent the effect of a change in the returns of REITs on the optimal portfolio weight in REITs. In addition, we can measure the marginal effect of changes in $\rho_{R S}$ on the optimal portfolio weight in REITs by solving for $\partial W_{R}^{*} / \partial \rho_{R S}$, which gives:

$$
\partial W_{R}^{*} / \partial \rho_{R S}=\frac{\sigma_{R} \sigma_{S}}{\sigma_{R}^{2}+\sigma_{S}^{2}-2 \rho_{R S} \sigma_{S} \sigma_{R}}\left[\frac{2\left[r_{R}-r_{S}+A\left(\sigma_{S}^{2}-\rho_{R S} \sigma_{R} \sigma_{S}\right)\right]}{A\left(\sigma_{S}^{2}+\sigma_{R}^{2}-2 \rho_{R S} \sigma_{S} \sigma_{R}\right)}-1\right] .
$$

Equation (7) demonstrates the impact that a change in the REIT-Stock correlation can have on the optimal weight in REITs. The marginal effect is determined by the variances and covariances of security returns, the risk aversion constraint of the individual investor, the REIT risk premium, and the current REIT-stock correlation. And, for the interpretation, $\partial W_{R}^{*} / \partial r_{R}$ is divided by 100 to establish the approximate changes in the respective portfolio weights of REITs and stocks per $1 \%$ change in $r_{R}$. All of these findings can then help to determine which marginal effects equations should be used.

\section{Results and Analysis}

Two experiments are explored considering risk premium, $r_{s}-r_{b}$, of $0.006 \%$ and $0.12 \%$. Note that multiple ranges have been explored and results seem to have similar impact as those captured in these two ranges and hence are removed from the discussion. By employing the above equations this research finds the results as shown in Exhibit 2.

Since the risk premium between stocks and bonds is $0.006 \%$, the performance of REITs is slightly superior to that of stocks and bonds. It is observed that when the risk premium of REITs and stocks is equal to $1.5 \%$; the risk aversion A before level 7 tends to encourage investors to invest the majority of capital wealth in REITs, 
short sell the bonds and put very little money in stocks. Moreover, $\partial W_{R}^{*} / \partial r_{R}$ is heavily dependent on the degree of risk aversion of the individual investor. Therefore, when the risk aversion is increased, $\partial W_{R}^{*} / \partial r_{R}$ is decreased. However, $\partial W_{R}^{*} / \partial \rho_{R S}$ is also dependent on the investor's level of risk aversion, but the differences are not very obvious. When (For) $\mathrm{A}=1, \partial W_{R}^{*} / \partial \rho_{R S}$ is $-0.05 \%$, but it is just $-0.051 \%$ when $\mathrm{A}=10$. Similar results are obtained when the risk premium between REITs and stocks is $2.0 \%$ and $2.5 \%$. The results also reveal that when investors choose to have more risky investments in their portfolio, they have relatively higher stock-REITs correlation.

When the risk premium between stocks and bonds is taken as $0.012 \%$, similar results are also observed as shown in Exhibit 3.

Exhibit 2. Impacts of changes in REIT-stock correlation and expected REIT returns with $r_{S}-r_{b}=0.006 \%$.

\begin{tabular}{|c|c|c|c|c|c|c|c|c|c|c|c|c|}
\hline & & A & & & & & & & & & & \\
\hline$r_{R}-r_{S}$ & & 1 & 2 & 3 & 4 & 5 & 6 & 7 & 8 & 9 & 10 & $\uparrow \uparrow$ \\
\hline \multirow[t]{5}{*}{$1.5 \%$} & $\mathrm{WR}^{*}$ & 6.790 & 3.400 & 2.267 & 1.700 & 1.361 & 1.135 & 0.973 & 0.851 & 0.757 & 0.681 & $\downarrow 90 \%$ \\
\hline & WS* & 0.080 & 0.032 & 0.025 & 0.019 & 0.015 & 0.012 & 0.011 & 0.010 & 0.009 & 0.008 & $\downarrow 90 \%$ \\
\hline & $\mathrm{WB}^{*}$ & -5.870 & -2.432 & -1.292 & -0.719 & -0.376 & -0.147 & 0.017 & 0.139 & 0.235 & 0.311 & $\uparrow 105 \%$ \\
\hline & $\partial W_{R}^{*} / \partial r_{R}$ & 451.422 & 225.711 & 150.474 & 112.856 & 90.284 & 75.237 & 64.489 & 56.428 & 50.158 & 45.142 & $\downarrow 90 \%$ \\
\hline & $\partial W_{R}^{*} / \partial \rho_{R S}$ & -0.05000 & -0.05000 & -0.05100 & -0.05106 & -0.05110 & -0.05112 & -0.05114 & -0.05115 & -0.05117 & -0.05117 & $\downarrow 2.34 \%$ \\
\hline \multirow[t]{2}{*}{$2.0 \%$} & $\mathrm{WR}^{*}$ & 9.057 & 4.529 & 3.020 & 2.265 & 1.813 & 1.511 & 1.295 & 1.133 & 1.008 & 0.907 & $\downarrow$ \\
\hline & WS* & 0.053 & 0.027 & 0.018 & 0.014 & 0.011 & 0.009 & 0.008 & 0.008 & 0.006 & 0.006 & $\downarrow$ \\
\hline \multirow[t]{3}{*}{$\partial W_{R}^{*} / \partial r_{R}$} & $\mathrm{WB}^{*}$ & -8.110 & -3.556 & -2.038 & -1.279 & -0.824 & -0.520 & -0.303 & -0.141 & -0.014 & 0.087 & $\uparrow$ \\
\hline & $\partial W_{R}^{*} / \partial r_{R}$ & 451.422 & 225.711 & 150.474 & 112.856 & 90.284 & 75.237 & 64.489 & 56.428 & 50.158 & 45.142 & $\downarrow$ \\
\hline & $\partial W_{R}^{*} / \partial \rho_{R S}$ & -0.05002 & -0.05064 & -0.05084 & -0.05094 & -0.05100 & -0.05105 & -0.05107 & -0.05110 & -0.05111 & -0.05113 & $\downarrow$ \\
\hline \multirow[t]{5}{*}{$2.5 \%$} & $\mathrm{WR}^{*}$ & 11.314 & 5.658 & 3.772 & 2.830 & 2.264 & 1.887 & 1.618 & 1.416 & 1.258 & 1.133 & $\downarrow$ \\
\hline & WS* & 0.036 & 0.108 & 0.013 & 0.009 & 0.008 & 0.007 & 0.005 & 0.005 & 0.005 & 0.004 & $\downarrow$ \\
\hline & WB* & -10.350 & -4.676 & -2.785 & -1.839 & -1.272 & -0.894 & -0.623 & -0.421 & -0.263 & -0.137 & - \\
\hline & $\partial W_{R}^{*} / \partial r_{R}$ & 451.422 & 225.711 & 150.474 & 112.856 & 90.284 & 75.237 & 64.489 & 56.428 & 50.158 & 45.142 & $\downarrow$ \\
\hline & $\partial W_{R}^{*} / \partial \rho_{R S}$ & -0.04955 & -0.05040 & -0.05069 & -0.05083 & -0.05091 & -0.05097 & -0.05101 & -0.05104 & -0.05106 & -0.051 & $\downarrow$ \\
\hline
\end{tabular}

Exhibit 3. Impacts of changes in REIT-stock correlation and expected REIT returns with $\boldsymbol{r}_{S}-\boldsymbol{r}_{\boldsymbol{b}}=\mathbf{0 . 0 1 2} \%$.

\begin{tabular}{|c|c|c|c|c|c|c|c|c|c|c|c|c|}
\hline & & A & & & & & & & & & & \\
\hline$r_{R}-r_{S}$ & & 1 & 2 & 3 & 4 & 5 & 6 & 7 & 8 & 9 & 10 & $\uparrow$ \\
\hline \multirow[t]{3}{*}{$1.5 \%$} & $\mathrm{WR}^{*}$ & 6.826 & 3.414 & 2.276 & 1.708 & 1.366 & 1.139 & 0.976 & 0.855 & 0.760 & 0.684 & $\downarrow 90 \%$ \\
\hline & WS* & 0.193 & 0.096 & 0.065 & 0.048 & 0.040 & 0.033 & 0.029 & 0.025 & 0.022 & 0.020 & $\downarrow 90 \%$ \\
\hline & WB* & -6.019 & -2.510 & -1.341 & -0.756 & -0.406 & -0.172 & -0.005 & 0.121 & 0.218 & 0.296 & $\uparrow 105 \%$ \\
\hline$\partial W_{R}^{*} / \partial r_{R}$ & & 451.422 & 225.711 & 150.474 & 112.856 & 90.284 & 75.237 & 64.489 & 56.428 & 50.158 & 45.142 & $\downarrow 90 \%$ \\
\hline$\partial W_{R}^{*} / \partial \rho_{R S}$ & & -0.05112 & -0.05119 & -0.05121 & -0.05122 & -0.05122 & -0.05123 & -0.05123 & -0.04483 & -0.05124 & -0.05124 & $\downarrow 2.34 \%$ \\
\hline \multirow[t]{5}{*}{$2.0 \%$} & $\mathrm{WR}^{*}$ & 9.083 & 4.542 & 3.029 & 2.272 & 1.818 & 1.515 & 1.299 & 1.137 & 1.011 & 0.910 & $\downarrow$ \\
\hline & WS* & 0.176 & 0.088 & 0.059 & 0.044 & 0.036 & 0.030 & 0.026 & 0.022 & 0.020 & 0.018 & $\downarrow$ \\
\hline & $\mathrm{WB}^{*}$ & -8.259 & -3.630 & -2.088 & -1.316 & -0.854 & -0.545 & -0.325 & -0.159 & -0.031 & 0.072 & $\uparrow$ \\
\hline & $\partial W_{R}^{*} / \partial r_{R}$ & 451.422 & 225.711 & 150.474 & 112.856 & 90.284 & 75.237 & 64.489 & 56.428 & 50.158 & 45.142 & $\downarrow$ \\
\hline & $\partial W_{R}^{*} / \partial \rho_{R S}$ & -0.05066 & -0.05095 & -0.05105 & -0.05110 & -0.05113 & -0.05115 & -0.05117 & -0.04477 & -0.05118 & -0.05119 & $\downarrow$ \\
\hline \multirow[t]{5}{*}{$2.5 \%$} & $\mathrm{WR}^{*}$ & 11.340 & 5.671 & 3.781 & 2.836 & 2.269 & 1.891 & 1.621 & 1.419 & 1.261 & 1.135 & $\downarrow$ \\
\hline & WS* & 0.159 & 0.079 & 0.053 & 0.040 & 0.330 & 0.027 & 0.024 & 0.020 & 0.019 & 0.017 & $\downarrow$ \\
\hline & $\mathrm{WB}^{*}$ & -10.499 & -4.750 & -2.834 & -1.876 & -1.302 & -0.918 & -0.645 & -0.439 & -0.280 & -0.152 & - \\
\hline & $\partial W_{R}^{*} / \partial r_{R}$ & 451.422 & 225.711 & 150.474 & 112.856 & 90.284 & 75.237 & 64.489 & 56.428 & 50.158 & 45.142 & $\downarrow$ \\
\hline & $\partial W_{R}^{*} / \partial \rho_{R S}$ & -0.05019 & -0.05072 & -0.05090 & -0.05099 & -0.05104 & -0.05107 & -0.05110 & -0.05112 & -0.05113 & -0.051 & $\downarrow$ \\
\hline
\end{tabular}


When the risk premium between stocks and bonds gets higher, the investment weights in REITs increase. Again, similar results could also be noticed in the impact that a change in the REIT-Stock correlation has on the optimal weight in REITs. The results also show that the correlation is getting lower when the risk aversion level is raised. The obvious observation found in these two tables is about the potential benefits of increasing the weights of the stock investment. Therefore, from these two tables, we can conclude that when the risk aversion is increased, the weight of REITs in the portfolio is decreased and the weight in bonds is increased. Since the correlation coefficient between REITs and bonds is relatively low, the investors could instead invest in bonds for hedging against the risk of investing in REITs.

\section{Concluding Remarks}

This research uses the mean-variance approach to illustrate ways to maximize the utility of the optimal portfolio with varying degrees of risk aversion. Two different risk premiums between stocks and bonds, such as $0.006 \%$ and $0.012 \%$ are applied to examine the portfolio choices. When the risk premium of REITs and stocks is $1.5 \%$, investors with risk aversion equal to 1 to 6 are better off investing almost all capital in REITs, they can short sell the bonds and put a very small weight in stocks. Similarly, investors can also derive the same benefit even when the risk premium of REITs and stock is $2.0 \%$ with a risk aversion of 1 to 9 . However, when the risk premium of REITs and stock is $2.5 \%$, the investor's risk aversion factor does not matter, and it suggests that investors can short sell bonds and invest in REITs having a larger weight in the optimal portfolio. The marginal effect of changes in $\mathrm{rR}$ on the optimal portfolio weights in REITs is observed to have a sharp decline when risk aversion is increased. However, the impact of that change in the REIT-Stock correlation coefficient is non-existent as the optimal weight in REITs doesn't change when the risk aversion is increased. Therefore, the change in weights of REITs in the optimal portfolio is more important than the correlation between REITs and stock performance. Furthermore, the results also reveal that investors with higher risk tolerance can also mix in stock-REITs with higher correlation. Since REITs outperform stocks and bonds, more and more investors should tend to put higher weights in REITs to form their optimal portfolio. This research mainly employs the mean-variance approach to find out the best utility maximizing portfolio mix with varying degree of risk aversion. Furthermore, the results from Grandmont-Gariboldi (2010) using an ex-post mean-variance analysis on the significance of REITs in international portfolios support some of the results from this study that the inclusion of REITs in a domestic and also in international portfolios could contribute to superior performance in a mean-variance framework.

Future research should investigate this issue in various countries considering the time period before and after the financial collapse of 2008. The performance of stock markets since 2008 around the world is not as stellar as they have been historically. The financial market players seem more cautious because of the experience of 2008 and the whole financial environment around the world seems unstable. Therefore, there is considerable debate and discussion that the returns from equity going forward may under-perform historical levels.

Finally, the findings from this research and the literature indicate that the expected return of REITs relative to that of stocks is a much more important factor than the REIT-stock correlation in making portfolio decisions. Although the data are different from the past, the results reflect the similar conclusions. A $1 \%$ change in the forecasted return for REITs, holding the stocks return fixed, has a dramatic impact in optimal portfolio allocations for investors of all risk levels. Therefore, the investors should consider the best way to maximize their return depending on their risk aversion, and the relationship between stocks and REITs.

\section{REFERENCES}

[1] S. J. Benjamin, A. Niskkalan and M. S. Marathamuthu, "Fair Value Accounting and the Global Financial Crisis: The Malaysian Experience,” Journal of Applied Management Accounting Research (JAMAR), Vol. 10, No. 1, 2012, pp. 23-36.

[2] C. F. Sirmans and E. Worzala, “International Direct Real Estate Investment: A Review of the Literature,” Urban Studies, Vol. 40, No. 5-6, 2003, pp. 1081-1114. http://dx.doi.org/10.1080/0042098032000074335

[3] E. Worzala and C. F. Sirmans, “Investing in International Real Estate Stocks: A Review of the Literature,” Urban Studies, Vol. 40, No. 5-6, 2003, pp. 1115-1149. http://dx.doi.org/10.1080/0042098032000074344

[4] H. R. Fogler, “20\% in Real Estate: Can Theory Justify It?” Journal of Portfolio Management, Vol. 10, No. 2, 1984, pp. 6-13. http://dx.doi.org/10.3905/jpm.1984.6

[5] P. Firstinberg, S. Ross and R. Zisler, "Real Estate: The Whole Story,” Journal of Portfolio Management, Vol. 14, No. 3, 1988, pp. 22-34. http://dx.doi.org/10.3905/jpm.1988.409154

[6] R. M. Ennis and P. Burik, “Pension Fund Real Estate Investment under a Simple Equilibrium Pricing Model,” Financial Ana- 
lysts Journal, Vol. 47, No. 3, 2006, pp. 20-30.

[7] J. G. Kallberg, C. H. Liu and W. D. Greig, “The Role of Real Estate in the Portfolio Allocation Process,” Real Estate Economics, Vol. 24, No. 3, 1996, pp. 359-377. http://dx.doi.org/10.1111/1540-6229.00695

[8] S. M. Giliberto, “The Allocation of Real Estate to Future Mixed-Asset Institutional Portfolios,” Journal of Real Estate Research, Vol. 7, No. 4, 1992, pp. 423-432.

[9] J. R. Webb, R. J. Curcio and J. H. Rubens, “Diversification Gains from Including Real Estate in Mixed-Asset Portfolios,” Decision Sciences, Vol. 19, No. 3, 1988, pp. 434-452. http://dx.doi.org/10.1111/j.1540-5915.1988.tb00278.x

[10] G. R. Mueller, K. Pauley and W. A. Morrell, “Should REITs Be Included in a Mixed-Asset Portfolio?” Real Estate Finance, Vol. 11, No. 1, 1994, pp. 23-28.

[11] A. G. Mueller and G. R. Mueller, “Public and Private Real Estate in a Mixed-Asset Portfolio,” Journal of Real Estate Portfolio Management, Vol. 9, No. 3, 2003, pp. 193-203.

[12] Ibbotson Associates, "New Analysis Validates Benefits of Including Real Estate as a Core Portfolio Holding,” 2003. WwW.NAREIT.com

[13] J. Goodman, "Homeownership and Investment in Real Estate Stocks," Journal of Real Estate Portfolio Management, Vol. 9, No. 2, 2003, pp. 93-105.

[14] D. Waggle and D. T. Johnson, "Home Ownership and the Decision to Invest in REITs," Journal of Real Estate Portfolio Management, Vol. 10, No. 2, 2004, pp. 129-144.

[15] V. L. Bajtelsmit and E. M. Worzala, “Real Estate Allocations in Pension Fund Portfolios,” Journal of Real Estate Portfolio Management, Vol. 1, No. 12, 1995, pp. 25-38.

[16] J. D. Benjamin, G. S. Sirmans and E. N. Zietz, "Returns and Risk on Real Estate and Other Investments: More Evidence," Journal of Real Estate Portfolio Management, Vol. 7, No. 3, 2001, pp. 183-214.

[17] B. E. Feldman, "Investment Policy for Securitized and Direct Real Estate,” Journal of Portfolio Management, Vol. 29, No. 5, 2003, pp. 112-121. http://dx.doi.org/10.3905/jpm.2003.319912

[18] M. J. Seiler, J. R. Webb and F. C. N. Myer, “Are REITs Real Estate?” Journal of Real Estate Portfolio Management, Vol. 5, No. 2, 1999, pp. 171-181.

[19] J. B. Corgel, W. McIntosh and S. H. Ott, "Real Estate Investment Trusts: A Review of the Financial Economics Literature," Journal of Real Estate Literature, Vol. 3, No. 1, 1995, pp. 13-43.

[20] E. J. Norman, G. S. Sirmans and J. D. Benjamin, “The Historical Environment of Real Estate Returns,” Journal of Real Estate Portfolio Management, Vol. 1, No. 1, 1995, pp. 1-24.

[21] E. N. Zietz, G. S. Sirmans and H. S. Friday, “The Environment and Performance of Real Estate Investment Trusts,” Journal of Real Estate Portfolio Management, Vol. 9, No. 2, 2003, pp. 127-165.

[22] S. Hudson-Wilson, F. J. Fabozzi and J. N. Gordon, “Why Real Estate?” Journal of Portfolio Management, Vol. 29, No. 5, 2003, pp. 12-25. http://dx.doi.org/10.3905/jpm.2003.319902

[23] S. L. Lee, "The Return due to Diversification of Real Estate to the U.S. Mixed-Asset Portfolio,” Journal of Real Estate Portfolio Management, Vol. 11, No. 1, 2005, pp. 19-28.

[24] P. Cheng and S. E. Roulac, "Measuring the Effectiveness of Geographical Diversification,” Journal of Real Estate Portfolio Management, Vol. 13, No. 1, 2007, pp. 29-44.

[25] M. Steinert and S. Crowe, "Global Real Estate Investment: Characteristics, Optimal Portfolio Allocation and Future Trends,” Pacific Rim Property Research Journal, Vol. 7, No. 4, 2001, pp. 223-239.

[26] S. A. Bond, G. A. Karolyi and A. B. Sanders, "International Real Estate Returns: A Multifactor, Multicountry Approach,” Real Estate Economics, Vol. 31, No. 3, 2003, pp. 481-500. http://dx.doi.org/10.1111/1540-6229.00074

[27] C. M. Conover, H. S. Friday and G. S. Sirmans, "Diversification Benefits from Foreign Real Estate Investments,” Journal of Real Estate Portfolio Management, Vol. 8, No. 1, 2002, pp. 17-25.

[28] T. M. Idzorek, M. Barad and S. L. Meier, “Global Commercial Real Estate-A Strategic Asset Allocation Study,” Journal of Portfolio Management, Vol. 33, No. 5, 2007, pp. 37-52. http://dx.doi.org/10.3905/jpm.2007.698904

[29] K. H. Liow, K. H. D. Ho, M. F. Ibrahim and Z. Chen, “Correlation and Volatility Dynamics in International Real Estate Securities Markets,” Journal of Real Estate Finance and Economics, Vol. 39, No. 2, 2009, pp. 202-223. http://dx.doi.org/10.1007/s11146-008-9108-4

[30] C. Jin, T. V. Grissom and A. J. Ziobrowski, “The Mixed Asset Portfolio for Asia-Pacific Markets,” Journal of Real Estate Portfolio Management, Vol. 13, No. 3, 2007, pp. 249-256.

[31] K. H. Liow, “The Dynamics of Return Volatility and Systematic Risk in International Real Estate Security Markets,” Journal of Property Research, Vol. 24, No. 1, 2007, pp. 1-29. http://dx.doi.org/10.1080/09599910701297663

[32] C. Yat-Hung, S. C.-K. Joinkey and T. Bo-Sin, “Time-Varying Performance of Four Asia-Pacific REITs,” Journal of Property Investment and Finance, Vol. 26, No. 3, 2008, pp. 210-231. http://dx.doi.org/10.1108/14635780810871605 
[33] K. H. Liow and A. Adair, “Do Asian Real Estate Companies Add Value to Investment Portfolio?” Journal of Property Investment \& Finance, Vol. 27, No. 1, 2009, pp. 42-64. http://dx.doi.org/10.1108/14635780910926667

[34] B. Ziering and W. McIntosh, "Revisiting the Case for Including Core Real Estate in a Mixed-Asset Portfolio,” Real Estate Finance, Vol. 14, No. 4, 1997, pp. 14-22.

[35] T. K. Philips, “Why Do Valuation Ratios Forecast Long-Run Equity Returns?” Journal of Portfolio Management, Vol. 25, No. 3, 1999, pp. 39-44. http://dx.doi.org/10.3905/jpm.1999.319714

[36] R. D. Arnott and P. L. Bernstein, “What Risk Premium Is Normal?” Financial Analysts Journal, Vol. 58, No. 2, 2002, pp. 6485. http://dx.doi.org/10.2469/faj.v58.n2.2524

[37] L. H. Hunt and D. M. Hoisington, “Estimating the Stock/Bond Risk Premium,” Journal of Portfolio Management, Vol. 29, No. 2, 2003, pp. 28-34. http://dx.doi.org/10.3905/jpm.2003.319870

[38] A. Ilmanen, “Forecasting U.S. Bond Returns,” Journal of Fixed Income, Vol. 7, No. 1, 1997, pp. 22-37. http://dx.doi.org/10.3905/jfi.1997.408197

[39] P. L. Bernstein, "What Rate of Return Can You Reasonably Expect... or What Can the Long Run Tell Us about the Short Run?” Financial Analysts Journal, Vol. 53. No. 2, 1997, pp. 20-38. http://dx.doi.org/10.2469/faj.v53.n2.2068

[40] C. B. Wainscott, "The Stock-Bond Correlation and Its Implications for Asset Allocation,” Financial Analysts Journal, Vol. 46, No. 4, 1990, pp. 55-60. http://dx.doi.org/10.2469/faj.v46.n4.55

[41] P. L. Bernstein, “How to Own Bonds and Enjoy It,” Journal of Portfolio Management, Vol. 23. No. 4, 1997, pp. 1-19. http://dx.doi.org/10.3905/jpm.23.4.1

[42] F. E. Dopfel, “Asset Allocation in a Lower Stock-Bond Correlation Environment,” Journal of Portfolio Management, Vol. 30, No. 1, 2003, pp. 25-38. http://dx.doi.org/10.3905/jpm.2003.319917

[43] S. Mull and L. Soenen, “U.S. REITs as an Asset Class in International Investment Portfolio,” Financial Analysts Journal, Vol. 53, No. 2, 1997, pp. 55-61. http://dx.doi.org/10.2469/faj.v53.n2.2072

[44] D. Waggle and P. Aggrrawal, “The Stock-REIT Relationship and Optimal Asset Allocations,” Journal of Real Estate Portfolio Management, Vol. 12, No. 3, 2006, pp. 209-221.

[45] D. Brounen and P. M. A. Eichholtz, "Property, Common Stock, and Property Stock-Increased Potential for Diversification," Journal of Portfolio Management, Vol. 29, No. 5, 2003, pp. 129-137. http://dx.doi.org/10.3905/jpm.2003.319914

[46] R. Bharati and M. Gupta, “Asset Allocation and Predictability of Real Estate Returns,” Journal of Real Estate Research, Vol. 7, No. 4, 1992, pp. 469-484.

[47] A. Ilmanen, "Expected Returns on Stocks and Bonds,” Journal of Portfolio Management, Vol. 29, No. 2, 2003 , pp. 7-27. http://dx.doi.org/10.3905/jpm.2003.319869

[48] T. J. Flavin and M. R. Wickens, “Macroeconomic Influences on Optimal Asset Allocation,” Review of Financial Economics, Vol. 12, No. 2, 2003, pp. 207-231. http://dx.doi.org/10.1016/S1058-3300(02)00072-1

[49] M. F. Giliberto, F. Hamelink, M. Hoesli and B. MacGregor, "Optimal Diversification within Mixed-Asset Portfolios Using a Conditional Heteroscedasticity Approach: Evidence From the U.S. and the U.K.,” Journal of Real Estate Portfolio Management, Vol. 5, No. 1, 1999, pp. 31-45.

[50] V. Chandrashekaran, “Time-Series Properties and Diversification Benefits of REIT Returns,” Journal of Real Estate Research, Vol. 17, No. 1, 1999, pp. 91-112.

[51] R. I. Anderson and T. M. Springer, "REIT Selection and Portfolio Construction: Using Operating Efficiency as an Indicator of Performance,” Journal of Real Estate Portfolio Management, Vol. 9, No. 1, 2003, pp. 17-28.

[52] A. C. Chui, S. Titman and K. C. J. Wei, “The Cross Section of Expected REIT Returns,” Real Estate Economics, Vol. 31, No. 3, 2003, pp. 451-479. http://dx.doi.org/10.1111/1540-6229.00073

[53] N. Grandmont-Gariboldi, "On the Significance of REITs in International Portfolios-A Canadian versus U.S. Perspective," Journal of Finance and Accountancy, Vo1. 4, 2010, pp. 92-112.

[54] S. I. Ivanov, "REIT ETFs Performance during the Financial Crisis,” Journal of Finance and Accountancy, Vol. 10, 2012, pp. 12-30. 